\title{
MODEL PEMBENTUKAN BRAND LOYALTY MELALUI REBRANDING DAN RATIONAL APPEALS
}

\author{
Ken Sudarti \\ Dewi Zahrotul Munifa Dila \\ Fakultas Ekonomi Universitas Islam Sultan Agung Semarang \\ kensudarti@unissula.ac.id
}

\begin{abstract}
In the competitive telecomunication industry, brand loyalty has become an important issue. Strong brand and marketing activity are becoming one of the critical levers for company's differentiation and successed. The aim of this study is to find the impact of rebranding and rational appeals on brand loyalty development while using brand image as mediator in Indosat Ooredoo. The sample consist of 100 respondent as Indosat Ooredoo consumer who live in Semarang. Through a structured questionnaire data were collected and with the help of SPSS, analysis was made. The results reveal that rational appeals and rebranding has significant effects on brand image. Rebranding has no impact on brand loyalty, while Indosat Ooredoo's rational appeals and brand image has significant effect on building consumer's brand loyalty. In the other side, rational appeals has directly impact on brand loyalty, while rebranding has undirect impact on loyalty throuh brand image as mediator.
\end{abstract}

Keywords: rebranding, rational appeals, brand image, brand loyalty

\section{PENDAHULUAN}

Industri telekomunikasi di Indonesia menghadapi gelombang kompetisi yang semakin ketat, munculnya pemain-pemain baru membuat persaingan meningkat. Banyaknya alternatif bagi konsumen membuat mereka cenderung kurang setia pada satu merek. Untuk itu penting bagi perusahaan dalam menerapkan berbagai strategi bisnis demi meraih dan meningkatkan loyalitas pada konsumen.

Loyalitas merek terhadap operator seluler di Indonesia masih sangat rendah, hal tersebut dibuktikan oleh churn rate (tingkat perpindahan konsumen ke pesaing) yang relatif tinggi, sebesar $11 \%$ sampai $20 \%$ per bulan. Tingginya churn rate pelanggan mendorong perusahaan harus mengetahui apa yang menjadi kebutuhan dan keinginan konsumennya demi terciptanya loyalitas merek konsumen. Salah satu faktor yang diyakini dapat mempengaruhi loyalitas merek adalah brand image (citra merek).

Brand (merek) bukan hanya sekedar nama, tanda, istilah atau simbol, didalamnya perusahaan memberikan fitur, manfaat dan layanan kepada para konsumen. Di era ini, pemasar berkompetisi membangun merek yang kuat demi memperoleh laba tinggi dan menguasai pasar. Brand image membantu perusahaaan menempatkan mereknya di benak konsumen.

Brand image merupakan persepsi tentang merek yang ada di dalam ingatan konsumen. Jika brand image mengalami penurunan artinya perusahaan perlu melakukan inovasi atau perbaikan pada strategi bisnisnya. Salah satu inovasi yang dapat digunakan perusahaan adalah rebranding. Rebranding adalah penciptaan kesan baru 
dan bagaimana memposisikannya di pikiran konsumen dengan membangun nama, slogan, tagline atau desain baru (Muzellec \& Lambkin, 2006). Demi mempertahankan merek dan loyalitas, rebranding dianggap sebagai salah satu strategi penting untuk mencapai kesuksesan dan meraih nilai merek (brand value).

Pada 19 November 2015, Indosat melakukan rebranding menjadi Indosat Ooredoo, alasannya perusahaan merasa perlu melakukan refresh, serta adanya perubahan stakeholder Indosat (Qtel) yang juga melakukan rebranding menjadi Ooredoo terlebih dahulu. Kegiatan rebranding yang dilakukan meliputi renaming (perubahan nama), redesign (perubahan logo), repositioning, hingga perubahan strategi pemasarannya.

Di sisi lain, untuk dapat bersaing dan bertahan di pasar dengan tingkat persaingan tinggi, perusahaan perlu memasarkan produk dan layanannya secara efektif, dimana iklan sebagai salah satu alat pemasaran dianggap sebagai alat pemasaran yang mendapat banyak perhatian (Afdahal, 1992). Pesan dalam iklan perlu diperhatikan, agar maksud yang diinginkan perusahaan menggunakan iklan tercapai. Hal tersebut dikarenakan iklan yang diterima konsumen mampu menghasilkan persepsi, yang disimpan dan sewaktuwaktu akan diingat dan diambil sebagai bahan untuk mengambil keputusan. Belch \& Belch (2001) menganggap pemilihan daya tarik iklan (advertising appeals) sebagai salah satu elemen dasar dalam strategi periklanan.

Sejalan dengan rebranding-nya, Indosat Ooredoo juga mempromosikan perubahan tersebut melalui iklan. Iklan tersebut menonjolkan daya tarik rasional, berupa keunggulan produk yang akan didapatkan. Iklan dikemas semenarik mungkin dengan ciri khas Indosat yang mempresentasikan perubahannya. Iklan tersebut menggambarkan fitur produk melalui semangat dan gebrakan muda yang syarat dengan kebebasan dalam memilih. Jargon "raih kebebasanmu sekarang" diharapkan dapat menjadi hal yang mudah diingat dan melekat di benak konsumen.

Berdasarkan apa yang telah dipaparkan di atas, maka perumusan masalah penelitian ini adalah "apakah kegiatan rebranding dan rational appeals yang dilakukan Indosat Ooredoo dapat mempengaruhi pembentukan brand loyalty konsumen Indosat Ooredoo dengan brand image sebagai variabel interveningnya?"

\section{KAJIAN PUSTAKA \\ Daya tarik rasional (rational appeals)}

Daya tarik iklan merupakan pendekatan yang digunakan untuk menarik perhatian konsumen dan menjadi alat yang mempengaruhi persepsi konsumen terhadap suatu produk, jasa, maupun ide (Mishra, 2009). Kotler (1991) memaparkan daya tarik iklan sebagai pengemasan produk, layanan, organisasi, maupun individu dalam berbagai cara untuk menyampaikan keuntungan, rangsangan, identifikasi, atau alasan yang ada di benak konsumen dan kenapa konsumen harus membeli produk tersebut. Daya tarik iklan didesain dalam bermacam bentuk untuk membuat citra positif pada individu yang menggunakan produknya. Menurut Belch \& Belch (1998), daya tarik iklan digunakan untuk menarik perhatian konsumen. Kotler (1997) mengungkapkan bahwa inti dari sebuah iklan adalah daya tarik iklan itu sendiri. Untuk membuat audiensnya dapat menerima pesan iklan dengan baik, pembuat iklan harus membubuhkan faktor penggerak yang disebut daya tarik yang mampu merangsang keinginan konsumen untuk melakukan pembelian. Oleh karena 
itu, daya tarik dianggap sangat penting karena dapat meningkatkan keberhasilan komunikasi dengan audiens (Sutisna, 2003).

Kotler (1991) mendefinisikan daya tarik rasional sebagai pembelian yang berorientasi rasional yang dirangsang dengan pemberian informasi tentang keuntungan produk secara langsung. Menurut Kotler \& Amstrong (1991), daya tarik rasional berhubungan dengan kepentingan audiens itu sendiri, hal ini ditunjukkan dengan produk yang dapat menghasilkan manfaat, seperti kualitas produk, nilai ekonomis, nilai produk maupun kemampuannya. Daya tarik rasional berasal dari informasi tradisional yang memproses model pengambilan keputusan yang beranggapan bahwa konsumen akan membuat keputusan logis dan rasional (Holbrook \& O'Shaughnessy, 1984).

Daya tarik yang umumnya ada pada daya tarik rasional yaitu daya tarik harga, daya tarik fitur, daya tarik keunggulan, daya tarik berita, dan daya tarik popularitas.

\section{Rebranding}

David Aaker (1997) mendefinisikan merek sebagai nama dan atau simbol yang bersifat membedakan (seperti sebuah logo, cap, atau kemasan) dengan maksud mengidentifikasi barang atau jasa dari seorang penjual atau sebuah produk tertentu, sehingga dapat membedakannya dari pesaing. Merek merupakan alat pemasaran utama saat ini dan penentu dalam membentuk citra (image) sebagai keunikan produk. Merek yang efektif mempermudah dalam mencapai tujuan pemasaran, seperti loyalitas merek (brand loyalty), merek berdasarkan harga premium, kesuksesan peluncuran produk, mempermudah pengambilan keputusan konsumen, dan mengurangi resiko konsumen (Aurand et al., 2005).

Muzellec \& Lambkin (2006) menjelaskan rebranding sebagai penciptaan nama baru, istilah, desain, atau gabungannya demi menciptakan merek yang kuat dengan tujuan memberikan perbedaan (posisi baru) dalam benak stakeholder dan pesaing. Rebranding merupakan kegiatan perubahan perusahaan atau target dan positioningnya dalam rangka menyematkan arti baru pada merek perusahaan dan mengkomunikasikannya kepada stakeholder (Stern, 2006).

Mazwahid (2012) menjelaskan ada beberapa alasan perusahaan melakukan rebranding, seperti alasan finansial, adanya manajemen/ kepemimpinan baru, analisa prospektif pasar, dan merger. Pada dasarnya proses rebranding terbagi dari beberapa tahapan (Muzellec \& Lambkin, 2006), yaitu repositioning sebagai proses penciptaan posisi baru, renaming, redesign, dan relaunch.

\section{Citra merek (brand image)}

Aaker (1994) mendefinisikan brand image sebagai serangkaian asosiasi yang ada dalam benak konsumen terhadap suatu merek, biasanya terorganisasi menjadi suatu makna tertentu. Keller (2003) dan Biel (1992) berpendapat bahwa brand image yang positif timbul saat konsumen mengasosiasikan dirinya pada merek tertentu dengan asosiasi unik dan munculnya keinginan untuk merekomendasikan merek tersebut kepada orang lain serta adanya sikap positif terhadap merek. Selain itu, brand image dianggap sebagai salah satu aspek kuat

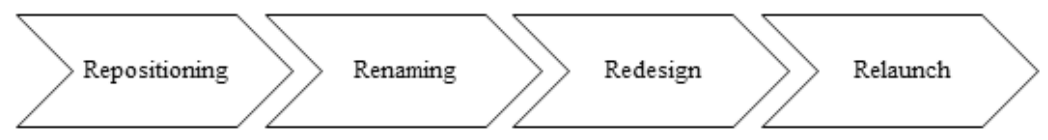

Gambar 1 Bauran Rebranding 
dalam membentuk reputasi merek di suatu pangsa pasar. Perusahaan atau produk yang memiliki citra baik di pasar cenderung memiliki tempat yang superior di pasar, keunggulan kompetitif yang signifikan, dan pangsa pasar yang besar.

Komponen pembentuk brand image terdiri dari citra pembuat, citra pemakai, dan citra produk. Pada dasarnya brand image dianggap efektif jika mampu menetapkan karakter merek apa yang akan diusung, dan didukung dengan penyampaian karakter secara berbeda sebagai diferensiasi tersendiri. Menurut Keller, brand image dapat diukur melalui tiga kategori, yaitu keuntungan asosiasi merek (favorability of brand association), kekuatan asosiasi merek (strength of brand association), dan keunikan asosiasi merek (uniqueness of brand association).

\section{Loyalitas merek (brand loyalty)}

Oliver (1999) mendifinisikan brand loyalty sebagai komitmen yang dipegang teguh untuk membeli ulang atau berlangganan dengan produk/ jasa yang disukai secara konsisten di masa datang, sehingga menimbulkan pembelian merek atau rangkaian merek yang sama secara berulang meskipun pengaruh situasional dan upaya pemasaran berpotensi untuk menyebabkan perilaku beralih merek Jacoby \& Chesnut (1987) menggarisbesarkan brand loyalty melalui beberapa pendekatan seperti, pendekatan sikap (attitudinal approach) berupa komitmen pembelian konsumen, pendekatan perilaku (behavioral approach) berupa frekuensi pembelian, dan pendekatan campuran (compound approach).

Brand loyalty memiliki beberapa tingkatan yang menggambarkan tantangan pemasaran yang berbeda pula (Aaker, 1997), tingkatan tersebut terbagi menjadi
: tidak loyal (no brand loyalty), konsumen yang puasa karena terbiasa satisfied/ habitual buyer (no reason to change), konsumen puas karena biaya beralih (satisfied buyer with switching cost), suka terhadap merek (likes the brand), konsumen dengan komitmen (commitement buyer).

Untuk memahami brand loyalty secara lebih jauh, penggunaan pendekatan sebagai alat ukur brand loyalty sangat disarankan. Salah satu pendekatan yang bisa digunakan adalah dengan mempertimbangkan perilaku aktual konsumen. Sedangkan pendekatan yang diambil dari konsep loyalitas seperti biaya peralihan (switching cost), kepuasan (satisfaction), kesukaan terhadap merek (liking the brand), dan komitmen (Aaker, 1997).

\section{Hubungan rational appeals terhadap brand image}

Rossiter \& Percy (1997) menjelaskan bahwa adanya tayangan iklan di televisi menimbulkan tanggapan dari masyarakat, dimana tanggapan tersebut berupa asosiasi merek (brand association) di dalam benaknya untuk menghasilkan brand image yang baik. Iklan diakui sebagai alat yang efektif dalam memasarkan produk (Jefkins, 1996). Untuk produk yang memiliki jenis dan karakteristik yang sama, iklan dapat digunakan sebagai sarana untuk menciptakan brand image sehingga produk tersebut mempunyai atribut yang unik dibandingkan produkproduk lain yang sejenis (Belch \& Belch, 2001). Oleh karena itu, salah satu cara yang dapat digunakan untuk menciptakan brand image adalah melalui pemilihan daya tarik iklan yang sesuai dengan motivasi yang dimiliki konsumen, baik motivasi rasional maupun emosional.

Penelitian yang dilakukan Muhammad Azhary (2015) membuktikan adanya pengaruh positif iklan televisi Tokopedia 
terhadap brand image perusahaan. Lebih lanjut lagi penelitian yang dilakukan oleh Diah Utami (2007) tentang pengaruh penggunaan daya tarik emosional dan rasional terhadap brand image pada kalangan remaja akhir perempuan juga menujukkan hasil yang signifikan. Hal ini juga didukung oleh hasil penelitian Septa, Husen dan Roy (2012) yang menunjukkan adanya pengaruh yang signifikan dari daya tarik iklan terhadap pembentukan brand image. Atas dasar pemikiran-pemikiran diatas, maka dirumuskan hipotesis sebagi berikut :

$\mathrm{H}_{1}$ : Rational appeals (daya tarik rasional) berpengaruh terhadap brand image (citra merek).

\section{Hubungan rebranding terhadap brand image}

Ester Tang (2009) mengungkapkan adanya hubungan positif antara rebranding dengan brand image. Pada dasarnya, strategi rebranding yang tepat mampu merubah persepsi konsumen, brand image, dan brand association. Menurut Keller (2009), strategi rebranding yang sukses dapat membantu meningkatkan akuitas merek (brand awareness dan brand image) sehingga berpengaruh terhadap peningkatan jumlah penjualan dan frekuensi konsumsi.

Penelitian yang dilakukan Azpizain Caniago et al. (2014) menunjukkan adanya pengaruh signifikan corporate rebranding tvOne terhadap pembentukan brand image perusahaan. Rizky Prananda (2015) dalam penelitiannya pada Bimo Trans juga memaparkan bahwa terdapat pengaruh positif antara rebranding terhadap brand image. Lebih jauh lagi, hasil penelitian yang dilakukan Bethani \& Natalia (2015) membuktikan bahwa rebranding yang dilakukan Universitas Telkom berpengaruh terhadap brand image universitas. Dari penjelasan singkat tersebut, maka dirumuskan hipotesis sebagai berikut:

$\mathrm{H}_{2}$ : Rebranding berpengaruh terhadap brand image (citra merek).

\section{Hubungan rational appeals terhadap brand loyalty}

Fungsi utama iklan adalah untuk meningkatkan kesadaran terhadap suatu brand (Moorthy \& Zhao, 2000). Literatur menunjukkan bahwa brand loyalty dan perceived quality berpengaruh positif terhadap merek, semakin banyak iklan suatu merek, semakin tinggi perceived quality dan loyalitas yang dimiliki konsumen pada sebuah merek (Yoo et al., 2000). Iklan merupakan metode yang paling penting dalam memberikan informasi, membentuk citra merek, dan meningkatkan penjualan serta keuntungan.

Africa Makasi et al. (2014) dalam penelitiannyamemaparkanadanyapengaruh positif advertising dalam membentuk brand awareness, brand loyalty, brand association, dan perceived quality. Penelitian lain yang dilakukan W.M.C.Bandara (2011) tentang pengaruh advertising appeals terhadap brand loyalty pada konsumen bank di Sri Lanka menenemukan adanya efek yang signifikan. Hal ini diperkuat oleh Matthew Sum (2004) yang menyatakan bahwa advertising merupakan pilihan yang efektif dalam membentuk brand loyalty. Dari pemaparan diatas, maka dirumuskan hipotesis sebagai berikut :

$\mathrm{H}_{3}$ : Rational appeals ( daya tarik rasional) berpengaruh terhadap brand loyalty (loyalitas merek).

\section{Hubungan rebranding terhadap brand loyalty}

Dalam upaya mempertahankan merek dan loyalitas pada konsumen, rebranding telah menjadi strategi penting 
dalam mencapai kesuksesan dan meraih nilai merek (brand values). Pemasar memandang rebranding sebagai salah satu cara untuk memperbarui merek yang sudah lama dan sebagai solusi untuk menghadapi persaingan pasar.

Penelitian yang dilakukan Ansory \& Lia (2014) menerangkan terdapat pengaruh rebranding terhadap loyalitas konsumen Fourspeed Nomad. Mavis et al. (2015) dalam penelitiannya yang berjudul Corporate branding and consumer loyalty in the telecommunication industry: a case study of MTN Ghana menunjukkan adanya pengaruh corporate branding terhadap penting dalam proses evaluasi layananan. Dalam literatur tentang merek, terdapat asumsi bahwa brand image yang baik mempunyai pengaruh positif terhadap kepuasan konsumen, dimana konsumen yang puas cenderung akan loyal pada suatu merek. Fry (2000) menemukan bahwa brand image memiliki pengaruh secara langsung pada loyalitas. Chun (2002) menyatakan bahwa brand image memiliki pengaruh tidak langsung terhadap loyalitas. Dari hal itu dapat dilihat bahwa brand image mempunyai kemungkinan pengaruh baik langsung maupun tidak langsung terhadap brand loyalty. Meskipun begitu, tetap saja

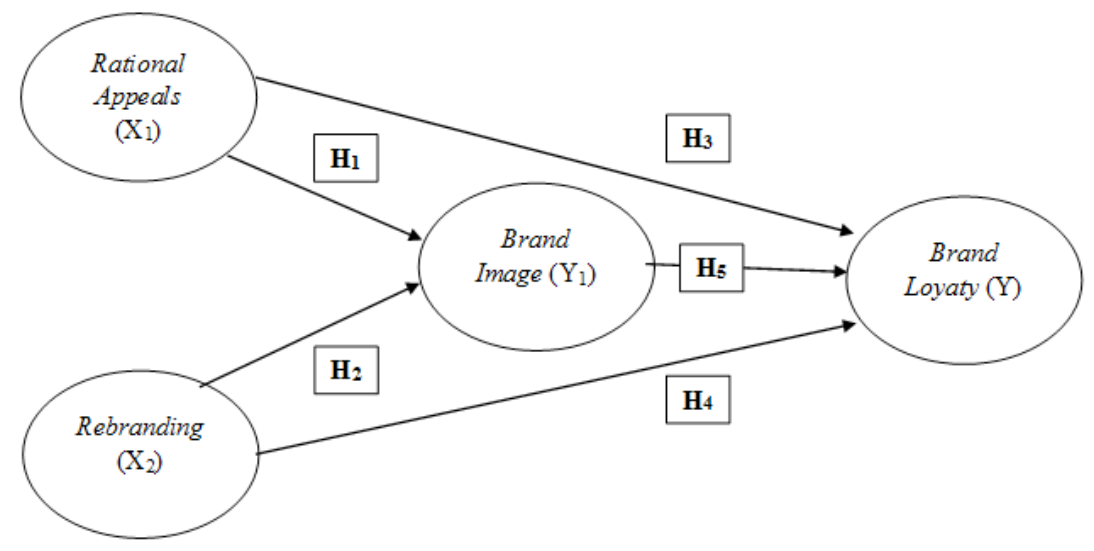

Gambar 2 Kerangka Pikir

loyalitas di industri telekomunikasi Ghana. Hal ini didukung oleh penelitian Makori M. Nyambane \& Makori M. Ezekiel (2013) bahwa terdapat pengaruh positif atas rebranding Kenya Power terhadap loyalitas pada konsumen Kenya Power. Atas dasar pemaparan diatas, maka dirumuskan hipotesis sebagi berikut :

$\mathrm{H}_{4}$ : Rebranding berpengaruh terhadap brand loyalty (loyalitas merek).

\section{Hubungan brand image terhadap brand loyalty}

Brand image dipandang sebagai faktor brand image menjadi salah satu alat prediksi bagi loyalitas konsumen pada suatu merek.

Rasheed et al. (2013) menjelaskan bahwa brand image berpengaruh signifikan terhadap brand loyalty dan costumer satisfaction. Selain itu, Danny Alexander (2014) dalam penelitiannya pada PT. Ades Alfindo Putra Setia memaparkan adanya pengaruh positif brand image terhadap brand loyaly. Didukung oleh penelitian yang dilakukan Grace Kavenyagi (2013) bahwa terdapat pengaruh positif brand image Kenya Commercial Bank (KCB) terhadap loyalitas konsumen secara langsung. Dari 
penjelasan singkat diatas, maka dirumuskan hipotesis sebagai berikut:

$\mathrm{H}_{5}$ : Brand image (citra merek) berpengaruh terhadap brand loyalty (loyalitas merek).

\section{Metode Penelitian}

Desain penelitian yang digunakan adalah penelitian eksplanatori (eksplanatory research) yaitu penelitian yang menjelaskan hubungan kasual antara variabel-variabel yang mempengaruhi hipotesis (Sugiyono, 2006).

Populasi pada penelitian ini adalah konsumen layanan telepon seluler Indosat Ooredoo di Semarang. Adanya keterbatasan yang dihadapi peneliti karena jumlah populasi yang banyak sehingga teknik sampling yang dipilih adalah non probability sampling dengan metode bertingkat. Pertama, pemilihan sampel dilakukan dengan purposive sampling, dimana syarat yang harus dimiliki responden yaitu, telah menjadi konsumen Indosat Ooredoo selama satu tahun dan sadar atau mengetahui iklan Indosat Ooredoo di televisi. Kemudian, dalam operasionalnya menerapkan accidental sampling, dimana pemilihan responden didasarkan pada aksesbilitas dan kedekatan peneliti kepada responden. Penentuan jumlah sampel dilakukan dengan menggunakan rumus Wibisono dengan jumlah minimal 96 responden.

Kuesioner terstruktur digunakan sebagai alat utama dalam mengumpulkan data primer. Hasil kuesioner dianalisis menggunakan teknik analisis jalur (path analysis) untuk mengetahui pola hubungan pengaruh langsung maupun tidak langsung dalam penelitian. Untuk memastikan bahwa kualitas data kuesioner valid dan handal dilakukan uji validitas dan reliabiitas terlebih dahulu. Kemudian dilakukan uji asumsi klasik sebagai persyaratan sebelum melakukan analisis untuk menjamin bahwa data yang didapat normal, dan mencegah adanya perantara yang mengganggu proses pengumpulan data dan proses interpretasi. Pendekatan kuantitatif digunakan untuk proses analisis data menggunakan program SPSS (Statistical Package for Social Science) 24.

\section{Hasil}

Tabel 1 di bawah menunjukkan hasil dari uji hipotesis model 1 (rational appeals dan rebranding terhadap brand image):

Table 1 Uji Hipotesis Model 1

\begin{tabular}{ccccc}
\hline & Model & $\begin{array}{c}\text { Standardized } \\
\text { Coefficient } \\
\text { Beta }\end{array}$ & t & Sig. \\
& & & 2,258 & 0,026 \\
\hline 1 & (Constant) & & 4,917 & 0,000 \\
& rational appeals $\left(X_{1}\right)$ & 0,461 & 2,931 & 0,004 \\
\hline & rebranding $\left(\mathrm{X}_{2}\right)$ & 0,275 & & \\
\hline
\end{tabular}

Berdasarkan hasil uji SPSS di atas, maka persamaan regresi yang mencerminkan variabel-variabel dalam penelitian ini adalah:

$Y_{1}=0,461 X_{1}+0,275 X_{2}+e_{1}$

Dari hasil uji hipotesis tersebut dapat dilihat untuk variabel $\mathrm{X}_{1}$ (rational appeals) diperoleh nilai t-hitung $(4,917)>\mathrm{t}$-tabel $(1,985)$ dengan tingkat signifikansi 0,000 , maka $\mathrm{Ho}$ ditolak dan $\mathrm{H}_{1}$ diterima, yang artinya ada pengaruh antara variabel rational appeals $\left(\mathrm{X}_{1}\right)$ terhadap variabel brand image $\left(\mathrm{Y}_{1}\right)$. Sedangkan untuk variabel $\mathrm{X}_{2}$ (rebranding) diperoleh nilai t-hitung $(2,931)>$ t-tabel $(1,985)$ dengan tingkat signifikansi 0,004 , maka Ho ditolak dan $\mathrm{H}_{1}$ diterima, yang artinya ada pengaruh antara variabel rebranding $\left(\mathrm{X}_{2}\right)$ terhadap variabel brand image $\left(\mathrm{Y}_{1}\right)$.

Table 2 Rational appeals dan rebranding terhadap brand image

\begin{tabular}{ccccc}
\hline Model & R & R Square & Adjusted R Square & Std. Error of the Estimate \\
\hline 1 & 0,659 & 0,434 & 0,423 & 2,742 \\
\hline & & \\
\multicolumn{3}{c}{ Berdasarkan } & tabel diatas, dapat \\
diketahui bahwa & koefisien determinasi
\end{tabular}

EKOBIS Vol. 21, No.1, Januari 2020 : 12 - 25 
(Adjusted $R$ Squared) sebesar 0,423. Hal ini berarti rational appeals dan rebranding berpengaruh terhadap brand image sebesar $42,3 \%$, sedangkan sisanya $57,7 \%$ dipengaruhi oleh variabel-variabel lainnya.

Table 3 Uji Hipotesis Model 2

\begin{tabular}{ccccc}
\hline & Model & $\begin{array}{c}\text { Standardized } \\
\text { Coefficient } \\
\text { Beta }\end{array}$ & t & Sig. \\
& & & 0,377 & 0,707 \\
\hline 1 & (Constant) & 0,444 & 4,085 & 0,000 \\
& rational appeals $\left(\mathrm{X}_{1}\right)$ & 0,020 & 0,201 & 0,841 \\
& rebranding $\left(\mathrm{X}_{2}\right)$ & 0,235 & 2,236 & 0,028 \\
\hline & brand image $\left(\mathrm{Y}_{1}\right)$ & 0 & &
\end{tabular}

Berdasarkan hasil uji hipotesis model 2 di atas, maka persamaan regresi yang menggambarkan variabel-variabel dalam penelitian ini adalah:

$$
Y=0,444 X_{1}+0,020 X_{2}+0,235 Y_{1}+e_{1}
$$

Dari hasil uji hipotesis tersebut dapat dilihat untuk variabel $\mathrm{X}_{1}$ (rational appeals) diperoleh nilai t-hitung $(4,085)>\mathrm{t}$-tabel $(1,985)$ dengan tingkat signifikansi 0,000 , maka $\mathrm{Ho}$ ditolak dan $\mathrm{H}_{1}$ diterima, yang artinya ada pengaruh antara variabel rational appeals $\left(\mathrm{X}_{1}\right)$ terhadap variabel brand loyalty $(\mathrm{Y})$. Dan untuk variabel $\mathrm{X}_{2}$ (rebranding) diperoleh nilai t-hitung $(0,201)$ $<\mathrm{t}$-tabel $(1,985)$ dengan tingkat signifikansi 0,841, maka Ho diterima dan $\mathrm{H}_{1}$ ditolak, yang artinya tidak ada pengaruh antara variabel rebranding $\left(\mathrm{X}_{2}\right)$ terhadap variabel brand loyalty $(\mathrm{Y})$. Sedangkan, untuk variabel $\mathrm{Y}_{1}$ (brand image) diperoleh nilai t-hitung $(2,236)>$ t-tabel $(1,985)$ dengan tingkat signifikansi 0,028 , maka Ho ditolak dan $\mathrm{H}_{1}$ diterima, yang artinya ada pengaruh antara variabel brand image $\left(Y_{1}\right)$ terhadap variabel brand loyalty $(\mathrm{Y})$.

Table 4 Rational appeals, rebranding, dan brand image terhadap brand loyalty

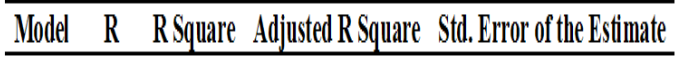

\begin{tabular}{lllll}
\hline 2 & 0,631 & 0,398 & 0,379 & 4,647 \\
\hline
\end{tabular}

Dari hasil perhitungan diatas, dapat dilihat bahwa koefisien determinasi (Adjusted $R$ Squared) sebesar 0,379. Hal ini berarti rational appeals, rebranding, dan brand image berpengaruh terhadap brand loyalty sebesar $37,9 \%$, sedangkan sisanya $62,1 \%$ dipengaruhi oleh variabel-variabel lainnya.

Penggunaan analisis jalur (path analysis) berfungsi untuk menganalisis pengaruh langsung dan tidak langsung yang terjadi pada model penelitian. Pengujian analisis jalur pada penelitian ini adalah:

Table 5 Hasil Uji Intervening

\begin{tabular}{ccccc}
\hline & Model & $\begin{array}{c}\text { Standardized } \\
\text { Coefficient } \\
\text { Beta }\end{array}$ & t & Sig. \\
& & & 0,377 & 0,707 \\
\hline $1 \quad$ Constant) & & & \\
& rational appeals $\left(\mathrm{X}_{1}\right)$ & 0,444 & 4,085 & 0,000 \\
& rebranding $\left(\mathrm{X}_{2}\right)$ & 0,020 & 0,201 & 0,841 \\
& brand image $\left(\mathrm{Y}_{1}\right)$ & 0,235 & 2,236 & 0,028 \\
\hline
\end{tabular}

Dari hasil tersebut dapat disimpulkan bahwa rational appeals berpengaruh secara langsung terhadap brand loyalty. Hal ini disebabkan nilai direct effect $(0,892)>$ indirect effect $(0,218)$. Sehingga variabel brand image mempunyai peran yang tidak terlalu signifikan sebagai mediator antara variabel rational appeals terhadap variabel brand loyalty. Sedangkan pada variabel independen kedua membuktikan bahwa rebranding tidak berpengaruh terhadap brand loyalty yang dibuktikan dengan nilai t-hitung yang lebih kecil dari t-tabel dan nilai sig. yang lebih besar dari taraf signifikansi yang telah ditetapkan. Tetapi disisi lain, hasil penelitian membuktikan bahwa rebranding berpengaruh terhadap brand image, dimana brand image dapat mempengengaruhi brand loyalty. Sehingga dapat disimpulkan bahwa variabel brand image mempunyai peran yang signifikan dalam memediasi variabel rebranding terhadap variabel brand loyalty.

\section{Pembahasan}

Berdasarkan hasil yang diperoleh menu- 
njukkan bahwa daya tarik rasional (rational appeals) yang digunakan Indosat Ooredoo memberikan pengaruh positif secara signifikan terhadap citra merek (brand image) Indosat Ooredoo. Ini berarti, semakin kredibel, kreatif, dan bermakna sebuah iklan, maka semakin kuat pula citra merek yang akan terbentuk di benak adudiensnya. Hasil pada deskripsi variabel rational appeals menunjukkan bahwa responden menganggap layanan yang diberikan Indosat Ooredoo sesuai dengan apa yang ada di iklan, tidak melebih-lebihkan yang justru berakibat pada kurangnya rasa percaya konsumen pada perusahaan. Selain itu, kreatifitas iklan sebagai salah satu indikator rational appeals dianggap masih belum maksimal, sehingga perlu dilakukan perbaikan khususnya dalam proses kreatif pembentukan iklan.

Penelitian-penelitian terdahulu menyatakan bahwa iklan yang baik dan efektif harus kredibel (dapat dipercaya), dan kreatif (berbeda dari pesaing). Kredibilitas iklan dapat terwujud jika pesan iklan yang disampaikan sesuai dengan produk atau layanan nyata dari perusahaan. Disisi lain, semakin kreatif sebuah iklan kecenderungannya untuk bertahan lebih lama di benak konsumen juga akan semakin tinggi. Plummer (2006) dalam penelitiannya membuktikan bahwa iklan yang kreatif dapat menghasilkan perasaaan emosional di benak konsumen, sehingga dapat membentuk brand image yang kuat. Penelitian terkait dengan pengaruh rational appeals terhadap brand image yang dilakukan oleh Septa Adi Sasetya et al. (2012), menunjukkan bahwa terdapat pengaruh yang signifikan dari daya tarik iklan Pepsodent Ayah Adi dan Dika terhadap pembentukan citra merek pelajar di Bandung.

Adanya kesesuaian antara hasil hipotesis, teori, dan penelitian sebelumnya bahwa daya tarik iklan khususnya rational appeals memiliki pengaruh terhadap brand image suatu produk atau merek di benak konsumen. Dengan begitu hipotesis yang dirumuskan dimana $\mathrm{H}_{1}$ (rational appeals berpengaruh terhadap brand image) diterima.

Hasil lain menunjukkan bahwa kegiatan rebranding Indosat Ooredoo di tahun 2015 berpengaruh terhadap citra merek (brand image) Indosat Ooredoo. Hal ini berarti, semakin menyenangkan, bermakna, dan mudah diingat suatu perubahan yang dilakukan perusahaan, maka semakin baik juga persepsi konsumen terhadap brand image perusahaan..

Kegiatan rebranding yang meliputi penciptaan elemen identitas merek (brand identity) yang nantinya akan mempengaruhi brand image dan brand reputation di benak konsumen. Semakin menyenangkan, bermakna, dan mudah diingat suatu perubahan, semakin baik juga persepsi konsumen terhadap brand image perusahaan. Menurut Aidatu Abubakari (2016) dari seluruh elemen rebranding yang terdiri dari repositioning, renaming, redesign, dan relaunch, perubahan nama (renaming) mempunyai pengaruh paling besar terhadap persepsi konsumen pada brand image perusahaan, diikuti slogan dan perubahan warna.

Penelitian sebelumnya yang dilakukan oleh Rizky Prananda (2015) menunjukkan bahwa rebranding yang dilakukan Bimo Trans berpengaruh terhadap brand image perusahaan di benak konsumen.

Dengan demikian, terdapat kesesuaian antara hasil penelitian dengan teori yang dikemukakan di tinjauan pustaka dan mendukung penelitian sebelumnya bahwa kegiatan rebranding berpengaruh terhadap brandimage perusahaan dibenakkonsumen. Maka, hipotesis yang dirumuskan berupa $\mathrm{H}_{2}$ (rebranding berpengaruh terhadap brand 
image) diterima.

Hasil penelitian lain menunjukkan bahwa daya tarik rasional (rational appeals) yang diaplikasikan Indosat Ooredoo dalam iklannya memberikan pengaruh positif secara langsung terhadap loyalitas merek (brand loyalty) konsumen Indosat Ooredoo. Hal ini berarti semakin bermakna sebuah iklan maka respon positif yang diberikan konsumen akan semakin tinggi pula. Berdasarkan analisis deskripsi pada variabel rational appeals dengan indikator bermakna, berbeda/kreatif, dan dapat dipercaya/kredibel mengindikasikan bahwa dari ketiga indikator tersebut, bermakna mendapatkan skor tertinggi, disusul indikator berbeda/kreatif dan yang terakhir indikator dapat dipercaya/variabel. Hasil tersebut mengindikasikan bahwa konsumen dapat menangkap pesan/ informasi yang ingin disampaikan perusahaan melalui iklannya, baik berupa informasi fitur produk, harga produk, maupun manfaat-manfaat produk. Sebaliknya, indikator dapat dipercaya/ kredibel yang mendapatkan skor terendah membuktikan bahwa informasi iklan Indosat Ooredoo masih dianggap kurang kredibel oleh konsumen. Hal ini dapat terjadi jika dalam pembuatan iklan, perusahaan terlalu melebihkan informasi sehingga cenderung tidak sesuai dengan penawaran produk yang sesungguhnya, semakin jauh informasi yang diberikan dengan kenyataan, tingkat kepercayaan konsumen kepada perusahaan akan semakin turun. Penyebab lain adalah minimnya informasi yang diberikan perusahaan melalui iklan, jika informasi yang diberikan terlalu sedikit atau cenderung implisit menyebabkan pesan yang ditangkap oleh konsumen berbeda, sehingga dapat terjadi missed communication antara perusahaan dengan konsumen.

Kondisi yang terjadi pada penelitian ini diperkuat oleh teori yang disampaikan Berkman \& Gilson (1987), bahwa keterkaitan daya tarik iklan terhadap loyalitas menimbulkan alasan bagi konsumen untuk melakukan pembelian dan mempengaruhi sikapnya untuk loyal pada suatu merek tertentu. Khan \& Sindhu (2014) menemukan bahwa perusahaan provider yang menggunakan rational appeals dengan menonjolkan sisi informasional dianggap efektif dalam mempengaruhi perilaku konsumen. Semakin tinggi tingkat informasi manfaat produk yang diberikan respon positif konsumen terhadap produk tersebut juga akan semakin tinggi.

Penelitian sebelumnnya yang dilakukan W.M.C.Bandara (2011) menemukan adanya pengaruh yang signifikan pada penggunaaan advertising appeals terhadap brand loyalty konsumen bank di Sri Lanka.

Adanya kesesuaian antara hasil penelitian, teori pada tinjauan pustaka dan penelitian sebelumnya membuktikan bahwa rational appeals yang digunakan dalam sebuah iklan dapat mempengaruhi brand loyalty konsumen. Maka dapat disimpulkan bahwa hipotesis yang dibuat yaitu $\mathrm{H}_{3}$ (rational appeals berpengaruh terhadap brand loyalty) diterima.

Hubungan lain yang dibentuk menunjukkan bahwa kegiatan rebranding yang dilakukan Indosat Ooredoo tidak memiliki pengaruh signifikan terhadap pembentukan brand loyalty konsumen. Ini berarti perubahan yang dilakukan perusahaan baik dalam positioning, nama, desain, dan launching tidak mempengaruhi loyalitas merek konsumen Indosat Ooredoo.

Hasil menunjukkan bahwa responden merasa perubahan Indosat Ooredoo melalui kegiatan rebranding tidak begitu berpengaruh pada sikap ataupun loyalitas konsumennya terhadap merek Indosat Ooredoo. Hal tersebut dikarenakan Indosat 
Ooredoo (yang sebelumnya bernama Indosat) dianggap sebagai brand atau perusahaan yang sudah cukup besar sehingga performance dan kredibilitasnya tidak perlu diragukan lagi. Disisi lain, alasan Indosat Ooredoo melakukan rebranding bukan dikarenakan adanya nilai buruk atau permasalahan yang terjadi pada merek sebelumnya (Indosat), melainkan adanya perubahan pada stakehoder Indosat Ooredoo dan prospektif pasar dari sisi perusahaan, sehingga tidak terlalu berpengaruh terhadap perubahan maupun pembentukan loyaltias merek konsumennya terhadap perusahaan.

Pada penelitian-penelitian sebelumnya terdapat riset gap tentang pengaruh rebranding terhadap brand loyalty. Penelitian yang dilakukan Ansory Wiranata dan Lia Yuldinawati membuktikan bahwa rebranding yang dilakukan Fourspeed Nomad berpengaruh terhadap loyalitas konsumennya di Bandung. Sedangkan di sisi lain penelitian yang dilakukan Alexander C. Tevi membuktikan rebranding yang dilakukan salah satu perusahaan jaringan telepon di Nigeria tidak mempengaruhi sikap konsumennya (loyalitas) terhadap perusahaan tersebut.

Maka, berdasarkan hasil yang diperoleh menunjukkan bahwa hipotesis yang dibuat yaitu rebranding berpengaruh terhadap brand loyalty ditolak, atau hasil penelitian tidak mendukung mendukung penilitian yang dilakukan Ansory Wiranata dan Lia Yuldinawati dan perumusan hipotesis dimana $\mathrm{H} 4$ (rebranding berpengaruh terhadap brand loyalty) ditolak.

Berdasarkan hasil penelitian pada citra merek (brand image) menunjukkan adanya pengaruh signifikan terhadap loyalitas merek (brand loyalty) konsumen Indosat Ooredoo. Hal ini berarti, semakin kuat, unik, dan tinggi manfaat citra merek semakin besar pula kecenderungan konsumen untuk loyal pada suatu merek atau perusahaan. Hasil analisis deskripsi yang dilakukan pada brand image dengan indikator kuat (strengh), baik/ menguntungkan, dan unik mengindikasikan bahwa dari ketiga indikator tersebut, kuat (strength) mendapatkan skor tertinggi, disusul baik/menguntungkan, dan terakhir indikator unik. Maka, dapat diketahui bahwa responden sudah menganggap Indosat Ooredoo sebagai merek/ perusahaan yang cukup kuat dan berpengaruh. Sebaliknya, rendahnya skor yang didapat oleh indikator unik menunjukkan bahwa keunikan Indosat Ooredoo dalam membangun citranya di mata konsumen masih belum maksimal. Penyebabnya bisa saja karena perusahaan tidak fokus dalam membentuk image yang diinginkan, apakah untuk golongan remaja, bisnis, atau justru ingin membentuk image sebagai perusahaan yang fokus di bidang digital.

Hal tersebut didudukung oleh teori-teori yang menyatakan bahwa perusahaan atau produk yang mempunyai citra baik di mata konsumen akan memberikan posisi yang lebih baik di pasar, dan meningkatkan pangsa pasar (market share) dan kemampuan perusahaan. Sebagai tambahan, beberapa penelitian bahkan mengkonfirmasi bahwa brand image yang baik akan mengantarkan konsumen kepada loyalitas (Koo, 2003). Beberapa bukti empiris mengindikasikan jika manfaat (benefit) brand image berhubungan positif dengan loyalitas. Saat konsumen menerima manfaat sosial yang tinggi dari suatu brand image, mereka akan cenderung loyal pada produk atau perusahaan tersebut (Reynolds \& Betty, 1999). Penelitian sebelumnya yang dilakukan oleh Grace Kavenyagi (2013) tentang pengaruh brand image bank komersial terhadap kepuasan pelanggan dan loyalitas menghasilkan bahwa brand image memiliki faktor pengaruh 
terhadap loyalitas pelanggan bank di Kenya.

Maka, berdasarkan hasil yang diperoleh menunjukkan adanya kesesuaian teori pada tinjauan pustaka dengan hasil penelitian, serta mendukung penelitian yang dilakukan sebelumnya bahwa brand image mempunyai pengaruh yang signifikan terhadap pembentukan brand loyalty konsumen. Dengan begitu, rumusan hipotesis yang telah dibuat dimana $\mathrm{H}_{5}$ (brand image berpengaruh terhadap brand loyalty) diterima.

\section{SIMPULAN}

Seperti yang sudah dijabarkan diatas, penelitian ini menganalisis tentang pembentukan loyalitas merek (brand loyalty) melalui rebranding dan daya tarik rasional (rational appeals) dengan citra merek (brand image) sebagai variabel intervening. Hasil penelitian menunjukkan bahwa rational appeals dan rebranding yang dilakukan Indosat Ooredoo berpengaruh terhadap penciptaan atau perubahan brand image perusahaan. Hasil lain dari penelitian juga didapatkan bahwa rational appeals dan brand image mampu mempengaruhi pembentukan brand loyalty, sedangkan kegiatan rebranding tidak berpengaruh terhadap brand loyalty Indosat Ooredoo secara langsung. Sebagai tambahan, berdasarkan interpretasi analisis jalur diketahui bahwa rational appeals dianggap memiliki pengaruh langsung dalam pembentukan brand loyalty konsumen Indosat Ooredoo di Semarang. Sedangkan, kegiatan rebranding tidak berpengaruh terhadap brand loyalty. Tetapi, rebranding mempengaruhi brand image, dimana kemudian brand image dapat mempengaruhi brand loyalty, sehingga dapat disimpulkan bahwa rebranding berpengaruh tidak langsung terhadap brand loyalty dengan brand image sebagai variabel intervening.

Lebih jauh lagi, peneliti menyarankan kepada perusahaan dalam kegiatan pemasarannya agar lebih kredibel, hal tersebut dapat dilakukan dengan adanya kesesuaian informasi pada iklan dengan produk atau layanan nyata perusahaan tanpa mengesampingkan keunggulankeunggulan yang dimiliki. Disisi lain, penyampaian iklan secara eksplisit dan jelas mampu mengurangi kemungkinan kesalahan atau missed communication antara pesan yang ditangkap konsumen dengan apa yang ingin disampaikan pelanggan. Perusahaan juga diharapkan dapat menambah program loyalitas pelanggan seperti penciptaan komunitas pelanggan, kegiatan sosial bagi pelanggan, sistem point, hingga penghargaan (reward) demi meningkatkan loyalitas konsumennya yang masih tergolong dalam tingkat sedang.

Bagi peneliti selanjutnya disarankan untuk mengembangkan hasil dari penelitian dengan menambah variabel lain seperti komunitas sosial, digital media, dan faktor-faktor lain pembentuk brand loyalty. Penelitian tentang pembentukan brand loyalty melalui rebranding dan rational appeals juga disarankan agar dapat diimplementasikan pada sektor/jenis usaha lain, seperti perusahaan asuransi, bank, dan situs jual-beli online untuk mengetahui pengaruh yang ditimbulkan sama atau tidak. 


\section{DAFTAR PUSTAKA}

Aaker, D. A. (1991). Managing Brand Equity. New York: The Free Press.

Ababio, A. G., \& Yamoah , E. E. (2016). Effect of Advertising on the Brand Loyalty of Cosmetic Products among College Students. Ghana: International Review of Management and Marketing.

Abubakari, A. (2016). Corporate Rebranding and Corporate Brand Image: The Mediating Role of Marketing Communication. Ghana.

Ampadu, M. B. (2015). Corporate Branding and Costumer Loyalty in the Telecomunication Industry: A Case study of MTN Ghana. Ghana: Net Journal of Business Management, Vol.3(3), pp. 36-42.

Andhikara, C. T., \& Nurparamesti, S. K. (2011). Brand Revitalization. Jakarta: Binus Business Review, Vol.2, No.1.

Azhary, M. (t.thn.). Pengaruh Iklan Televisi "Tokopedia: Lebih Lengkap, Lebih Murah, Lebih Aman" terhadap Brand Image PT. Tokopedia. Jakarta.

Bastian, A. D. (2014). Analisa Pengaruh Citra Merek (Brand Image) dan Kepercayaan Merek (Brand Trust) Terhadap Loyalitas Merek (Brand Loyalty) ADES PT.Ades Alfindo Putra Setia. Surabaya: Jurnal Manajemen Pemasaran, Vol.2, No.1.

Caniago, A. (2014). The Effects of Service Quality and Corporate Rebranding on Brand Image, Costumer Satisfaction, Brand Equity and Costumer Loyalty. Malang: European Journal of Business and Management, Vol.6, No.19.

Julianto, A. (2006). Pengaruh Promosi terhadap Brand Image Sabun Mandi Lifebuoy, Skripsi. Universitas Widyatama.

Karmokar, P. K. (2014). All About Brands and Brand Building. United States: Innovative Space of Scientific Research Journals, Vol.3, No.1.

Kimberley, T. (2012). Rebranding to redefine international brand identity - A case study to evaluate the success of Sonera's branding.

Makasi, A., Govender, K., \& Rukweza, C. (2014). Buiding Brand Equity through Advertrising. Zimbabwe: Mediterranean Journal of School Sciences, Vol.5, No.20.

Masna, A. (2015, November 19). News: Addiction Web site. Diambil kembali dari Addiction Web site: http://addiction.id/indosatooredoo/

Nwankwo, B. E., Aboh, J. U., Obi, C. T., Agu, S. A., \& Sidney-Agbor, N. (2013). Influence of Advertising Appeals and Personality on Telecoms Consumption Preferences in Nigeria. International Journal of Academic Research in Business and Social Sciences, Vol. 3, No. 9.

Nyambane, M. M., \& Ezekiel, M. M. (2013). The Relationship between Rebranding and Costumer Loyalty: The Case of Kenya Power. Kenya: International Journal of Science and Research.

Onyancha, G. K. (2013). The Impact of Brand Image on Costumer Satisfaction and Loyalty: A Case of Kenya Commercial Bank. Kenya: European Journal of Business and Management, Vol.5, No.21.

Padgett, D., \& Allen, D. (1997). Communicating Experience: A Narrative Approach to Creating Service Brand Image. Journal of Advertising, pp. 49-62.

Saad, F. (2011). Saad, Faiza. 2011. Brand Loyalty through Emotional Advertising. Pakistan: 
Journal Marketing Philosohy \& Practice, Vol.1, No.1.

Sasetyo, S. A., Nawawi, H., \& Rondonuwu, R. (2012). Pengaruh Daya Tarik Iklan terhadap Pembentukan Citra Merek Pepsodent. Jakarta: eJurnal Mahasiswa Universitas Padjajaran, Vol.1, No.1.

Tjiptono, F. (2014). Pemasaran Jasa. Yogyakarta: Andi Offset.

Utami, D. (2007). Pengaruh Penggunaan Daya Tarik Emosional dan Rasional Secara Bersamaan dalam Iklan Cetak terhadap Citra Merek pada Remaja Akhir Perempuan. Universitas Diponegoro.

Wanniyanake, W. (t.thn.). Impact of Advertising Appeals on Brand Loyalty. Czech Republic.

Wiranata, A., \& Yuldinawati, L. (t.thn.). Pengaruh Rebranding terhadap Loyalitas Konsumen. Bandung, 2014.

You, Z., Zhang, X., \& Koyama Sinichi. (2013). Informational vs Emotional Appeals of Logo Design Influencing Purchase Intentions for Plant-factory-produced Vegetables. Japan: International Journal of Advances in Psychology, Vol.2, Issue 4.

Zarantonello, L., Schmitt, B. H., \& Jedidi, K. (2014). How to Advertise and Build Brand Knowledge Globlally: Comparing Television Adverising Appeals across Developed and Emerging Economies. Columbia: Journal of Advertising Research, Vol.54, No.4. 